\title{
Promoting Scrapbook as Media in School Literacy Movement
}

\author{
Gilang Fadhilia Arvianti1*, Atsani Wulansari1, Asri Wijayanti1 \\ ${ }^{1}$ Universitas Tidar \\ *Coresponding author: gilangfadhilia@untidar.ac.id
}

\section{ARTICLE INFO}

Article history:

Received: 24 Mei 2019

Accepted: 12 September 2019

\section{Keywords:}

kemampuan membaca, gerakan literasi sekolah, scrapbook

\begin{abstract}
ABSTRAK
Membaca merupakan salah satu cara untuk mempelajari suatu hal. Namun demikian beberapa faktor mempengaruhi motivasi dari siswa dalam membaca buku-buku materi, bahkan buku-buku cerita yang mudah. Gerakan Literasi Sekolah (GLS) merupakan salah satu program yang diselenggarakan oleh pemerintah untuk meningkatkan minat baca dari siswa, meskipun dibeberapa tempat program ini tidak berjalan sesuai dengan rencana pemerintah. Tujuan penelitian ini adalah meningkatkan pengetahuan guru untuk memotivasi siswa membaca buku dengan kegiatan yang menarik. Diharapkan dengan cara menarik ini, guru dapat mengajak siswa gemar membaca dan mereka dapat ikut menyukseskan program GLS. Langkah yang dilakukan yang pertama adalah guru diberikan pengetahuan mengenai teknik membaca cepat. Kemudian mereka diberikan pelatihan mengaplikasikan scrapbook sebagai kegiatan lanjutan setelah membaca. Setelah pelatihan tersebut, guruguru tertarik dan termotivasi untuk mengajarkan kepada siswa didiknya sehingga mereka dapat memahami isi bacaan dengan cara yang menyenangkan.
\end{abstract}

\section{INTRODUCTION}

The proverb said that reading is the window to the world. The more we read the book, the more knowledge we get. However, the reading interest in Indonesia is very low. The survey held by United Nations Educational, Scientific and Cultural Organization (UNESCO) stated that the reading interest of Indonesian citizen is only 0,001 (Puspita \& Irwansyah, 2018). Meanwhile, the IEA (International Association for the Evaluation of Education Achievermen) study showed Indonesia has the lowest position for children's reading interest (Wahyuni, 2019). Those facts are worrisome. As reading is one of the ways to gain the knowledge, the low literacy interest for most students in Indonesia is become a serious problem that affects education.

Wahyuni (2019) urged there are six factors making low reading interest. Six of them are lack of reading environment, economic factor, lack of good library, the development of electronic media, ineffective learning model, and inappropriate reading learning system. 
To overcome that problem, Indonesian government applies School Literacy Movement. This movement is based on the regulation of Minister of Education and Culture Number 23 year 2015 concerning character building. One of the main points in that regulation is the obligation to read non-text book for 15 minutes before the lesson starts in school. The purpose of School Literacy Movement is to increase students' literacy (Handayani, Adisyahputra, \& Indrayanti, 2018). Furthermore, it can be the way to increase students' critical thinking to overcome the hoax. The students lead to think more critically on the information through this School Literacy Movement. Hence, the good literacy is developed early through the family and school environment. School Literacy Movement is realized through the effort to make students get acquainted with books. It can be seen from the emergence of reading corner and library revitalization. Therefore, the school itself is also encouraged to develop the literacy activity in accordance with the school condition and need.

By observing the literacy movement in two elementary schools in South Magelang sub-district, it is showed that the majority of students have not shown their interest in literacy. Only a few students visit the reading corner in break time (Juhanda, \& Maryanto, 2018; Suhendar \& Wahyuni, 2018). Moreover, the ability of students to write the story is low. The lack of students' literacy awareness is caused by a lack of stimulus from the teacher in fostering interest in reading and writing. Then, to increase the students' reading interest, the writers introduce scrapbook to the teachers in those elementary schools (Azrai, Ernawati, \& Sulistianingrum, 2017). Scrapbook is the combination between picture and story. Thus, the aim of this research is to enrich teacher's knowledge to motivate students in reading book in fun activity in school literacy movement.

\section{METHODOLOGY OF RESEARCH}

The aim of this research is to enrich teacher's knowledge to motivate students in reading book in fun activity. Therefore, this research used a descriptive qualitative research. There were 22 participants in this research. This research took place in two elementary schools in South Magelang sub-district. The instrument of this research was questionnaire to investigate the teachers' perception. In this research, there were many stages done i.e. preparation stages, input stages, process stages and output stages. In preparation stages, the researchers determine the purpose of the activity which is to increase the School Literacy Movement. Then, in input stages, the researchers observed and collected the primary data to identify the problem in school literacy movement. After finding the problem, the researchers gave the training of making scrap book to the teachers. Last, the researchers evaluated the activity.

The data was analyzed by using Miles, Huberman and Saldana' data analysis technique (2014). This technique included data collection, data display, data reduction, and conclusion drawing and verification. The data were taken from the questionnaire given to teachers.

\section{LITERATURE REVIEW}

This part discuss some theories that used in this paper. Those theories are school literacy movement, speed-reading technique, and scrapbook as a media that is used to motivate student actively in enrich reading skill.

\section{School Literacy Movement}

To conquer the problem of the low interest in reading activity, the government launched the program School Literacy Movement (GLS). Regulation of the program is based on The Regulation of the Minister of Education and Culture No. 23 of 2015 which provides a focal point for basic education in Indonesia to explicitly implement and foster the values of character since students' orientation to their graduation. The development of GSL based on the Regulation of the Minister of Education and Culture No.23 of 2015 on 
the Development of Character Article 1 letter 4, "Habituation is a series of activities done by students, teachers, and educators aimed at developing a good habit and educate the generation to be a generation with positive character". This is related to reading books outside of the lessons for 15 minutes before the class starts. According to Faizah, et al. (2016:2), "GLS is aimed at enhancing the capacity of the students and the school staff to become literate." The activity is an effort to develop the love for reading in the students and pleasurable experience and at the same time stimulating the imagination.

There are some aims of the school literacy movement program which is mandated by the government. They are

1. Increasing culture of literacy in school

2. Making the school as a fun and child-friendly learning park so that the school residents are able to manage their knowledge

3. Maintaining the continuity of learning by presenting various books and accommodating a variety of reading strategies.

\section{Speed Reading Technique}

Speed reading is a type of techniques of reading that have priority of speeding in reading without left the understanding of the contents of the reading. The speed of reading depends on the material and purpose of reading and also the mastery of the reader on the contents of the reading. Zuchdi (2008: 24) says reading ability is related to the speed of reading and the understanding of reading content. This is influenced by linguistic competence, eye abilities, determination of focus information, reading techniques and methods, reading flexibility, and reading habits.

Speed reading activities can be done by reading silently. Tarigan (2015: 32)

mentions reading silently can be classified as intensive and extensive reading. Extensive reading includes survey reading, skimming, and superficial reading. On the other hand, intensive reading group is content study reading and linguistic study reading.

Based on Barbe and About in Tarigan (2015:39), there are some skill needed in reading silently, as followed:

1st grade 1) Reading silently, without lip movement, without wishpering

2) Reading without head movement

2nd grade 1) Reading without lip or head movement

2) Reading faster silently than reading aloud

3rd grade 1) Reading silently without pointing fingers, without lip movement

2) Comprehending the book which is read silently

3) Reading silently is faster than reading aloud

4 th grade 1) Understanding and comprehending book in basic level

2) The eyes' speed is able to read 3 words in a second.

5 th grade 1) Reading silently is really faster than reading aloud

2) Reading with better comprehension

3) Reading without lip or head movement, or pointing with fingers

4) Enjoying reading silently (more enjoy to read silently)

6th grade 1) Reading without lip movement

2) Able to adjust the speed of reading with the level of difficulty of the book

3) Able to read 180 word in a minute in fiction book basic level

\section{Scrapbook}

According to dictionary, scrapbook is a book with empty pages in which we can stick thing such as picture, article of newspaper in order to keep it. Scrapbook also can be define as a crafting and also documentation activity that involve book with blank pages then adding it with photos, recipe, greeting cards, pay bill, tickets, or anything else that 
wanted to be memorized. The sticking things usually add with some notes to make the owner of the scrapbook remember the activity behind the things they added.

With those definitions, scrapbook also can be a media to help teacher motivate students to do fun activity during school literacy movement. Scrapbook is one of fun and easy media to be applied in class even in elementary school. This media only need book to be read, the copy of the pictures, the empty book or can be changed with empty paper, and also stationary such as scissor, glue, and pen. If it is not possible to prepared the copies of the pictures, the teacher can asked the students to draw the picture based on the story they have read. It will be more creative and challenging.

There are some steps must be done by using scrapbook. First of all, the students must read the book that had been prepared previously. In here, the teacher also can modify or adding new skill in reading, for example during the teachers in these two schools are being taught speed-reading technique to read the book. By using this technique, it is hoped the time for school literacy are not only for read the book. After that, the book they have read are resubmitted again, therefore the teacher cannot do cheating or reopen the book again. The instructor distributed some pictures based on the story the teacher have read, an empty book, and also stationeries. In 10 minutes, they need to arrange the picture and also retelling the story based on the picture they have arranged and they have read.

\section{RESULT AND DISCUSSION}

As stated in introduction, the aim of this research is to enrich teacher's knowledge in motivating students to read book in fun activity. It is knowing that school literacy movement in the two elementary school in Magelang Selatan, school that is used as the partner of this research, have run as mandated by the government, but they did not held regularly.

The teachers in two elementary schools were being taught by using speed reading technique to improve their reading skill. This technique is chosen since GLS only provided 15 minutes to read and comprehend the book which is read. After that, the teachers were being treated by using scrapbook technique as fun activity in reading. In the end of practice session using scrapbook, the participant must fulfill the questioner to measure the effect they felt after learnt scrapbook.

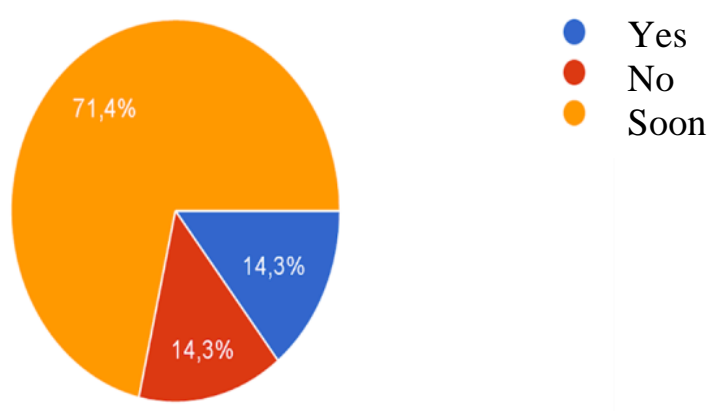

Picture 1. Response of the teacher who had applied Scrapbook in class

From the picture 1 above, it can be seen that most of the teacher never used scrapbook in their class. Only $14.3 \%$ of the teacher who took a part of this tutorial have known about scrapbook. The rest of the teacher claimed that they never used scrapbook and planned to use this technique in literacy time. Previously in their class, they only gave time for student to read the book. They use all 15 minutes for reading books they have 
provided in school literacy movement program. They think they cannot give the follow up activity after the students read the book since they read different title of the book.

As we know that one purpose of the school literacy movement is to maintaining the continuity of learning by presenting various books and accommodating a variety of reading strategies. Therefore, the teachers believe that scrapbook fits with the needs of the school literacy. It can be seen through the result of the questioner which asked whether the scrapbook is suitable and fits with school literacy program or not. The result showed that all of the teachers are agree with that statement. It can be seen the following diagram which showed the response of the teachers who are asked about scrapbook dealt with the school literacy movement program.

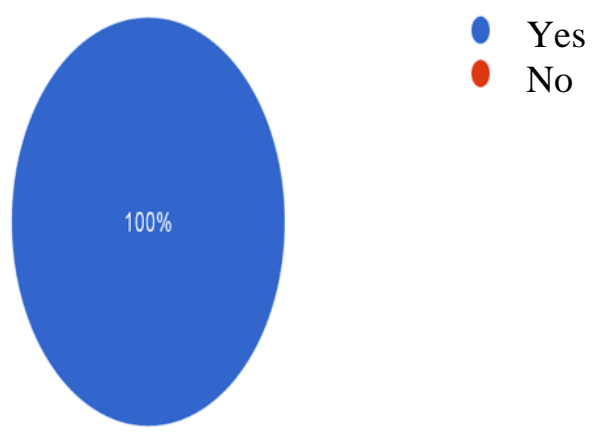

Picture 2. Response whether the scrapbook fits with needs of school literacy program

Scrapbook is one the techniques that can be used as the followed up activity after the students read the book. The point of scrapbook is the students able to retell the story in fun way. They only need to arrange the picture which told about the story and give the caption or the story of each picture. The teachers are interest to apply scrapbook after they are being taught this technique. They believed that scrapbook is easy to apply and kind of fun activity if this activity is applied in the class. They believed that all of students in all grades can do this activity with their guide. This technique can be used as the one of the activity in school literacy movement. This statement is in line with the result of the questioner filled by the teacher who has being taught scrapbook as the technique and media in reading activity. All the teachers are agree that scrapbook is easy to be applied in the class. It can be seen in picture 3 as followed.

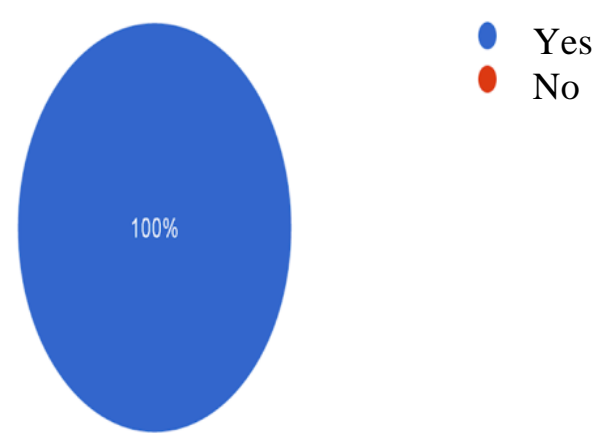

Picture 3. Response that Scrapbook is easy to apply in class

Being asked whether scrapbook is very useful in increasing children's interest in reading book or not, the teachers are agree that scrapbook is very useful. Not 
only easy to be applied, scrapbook is also able to increase students' interest in reading. When the teachers are being taught using scrapbook, they felt challenged to arrange the pictures that are provided previously. after that they need to retell the story they have read which also describe the picture is about. Sometimes the teachers which are divided into some groups, have different opinion to retell the story about the picture, or sometimes they also misarrange the picture that make the story are different with the story they have read. That is why scrapbook is thought as one of the best media in reading comprehension since in scrapbook, the readers are need to read, memorize, and retell the story they have read. This method can be use to measure the student's comprehension after they read the story. The result of the questioner can be seen in the following picture.

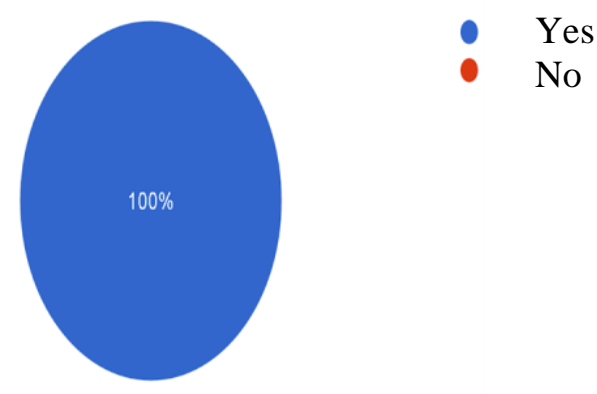

Picture 4. Response whether scrapbook is useful in increasing childrens' interseting in reading

\section{CONCLUSION}

From the result of the questioner and the discussion above, teachers in elementary schools which are partner of this research, are agree that although some of them never applied scrapbook in their class, they believed that scrapbook fits with the needs of school literacy movement program. They also think that scrapbook is easy to applied in class since scrapbook can increase students' interest in reading book. Therefore it can be conclude that scrapbook can be applied in the class as follow up activity in school literacy movement as mandated by the government.

\section{REFERENCES}

Azrai, E. P., Ernawati, E., \& Sulistianingrum, G. (2017). Pengaruh Gaya Belajar David Kolb (Diverger, Assimilator, Converger, Accommodator) Terhadap Hasil Belajar Siswa Pada Materi Pencemaran Lingkungan. Biosfer: Jurnal Pendidikan Biologi, 10(1), 9-16.

Faizah, D. U, Sufyandi, S, Anggraini, L, Waluyo, Dewayani, S, Muldian, W, Roosaria, D. R. 2016. Panduan Gerakan Literasi di Sekolah Dasar. Jakarta: Direktorat Jenderal Pendidikan Dasar dan Menengah Kementerian Pendidikan dan Kebudayaan.

Handayani, G., Adisyahputra, A., \& Indrayanti, R. (2018). Correlation between integrated science process skills, and ability to read comprehension to scientific literacy in biology teachers students. Biosfer: Jurnal Pendidikan Biologi, 11(1), 22-32.

Juhanda, A., \& Maryanto, Y. (2018). The emergence of biological problems in electronic school books (bse) class x reviewed from the scientific knowledge domain of scientific literacy. Biosfer: Jurnal Pendidikan Biologi, 11(2), 121-125. 
Puspita, G. A., \& Irwansyah. (2018). Pergeseran Budaya Baca dan Perkembangan Industri Penerbitan Buku di Indonesia: Studi Kasus Pembaca E-Book Melalui Aplikasi iPusnas. BIBLIOTIKA: Jurnal Kajian Perpustakaan Dan Informasi, 2(1), 13-20.

Suhendar, S., \& Wahyuni, A. (2018). Achievement and response of students at favorite junior high schools in sukabumi on trends in international mathematics and science study (timss) questions. Biosfer: Jurnal Pendidikan Biologi, 11(2), 126133.

Tarigan, Henry Guntur. 2015. Membaca sebagai Suatu Keteramoilan Berbahasa. Bandung: Angkasa.

Wahyuni, S. (2019). Menumbuhkembangkan Minat Baca Menuju Masyarakat Literat. Diksi, 16(2), 179-189. https://doi.org/10.21831/diksi.v16i2.6617

Zuchdi, Darmiyati. 2008. Strategi Meningkatkan Kemampuan Membaca (Peningkatan Komprehensi). Yogyakarta: UNY Press. https://www.thesprucecrafts.com/whatis-scrapbooking-2960505 